\title{
A case of thyroidectomy in the Charaf ed-Din's manuscript (1465)
}

\author{
E. Martino ${ }^{1} \cdot$ L. Macrì $^{1} \cdot$ S. Mariotti ${ }^{2}$
}

Received: 15 July 2020 / Accepted: 27 August 2020 / Published online: 1 September 2020

(C) Italian Society of Endocrinology (SIE) 2020

Charaf ed-Din (1385-c.1468) was an innovative surgeon and a prominent illustrator who lived in the Ottoman Empire during the fifteenth century. His medical treatise, Cerrahiyyet'ül-Haniyye (Imperial Surgery, 1465), is the first illustrated surgical textbook written in Turkish. His book also provides comprehensive information about ancient Greek and Islamic knowledge of medicine, mostly based on the comprehensive Arabic medical text Kitab al-Tasrif (The Method of Medicine) by the physician Abu al-Qasim al-Zahrawi (936-1013) [1, 2].

Fragments of the Charaf ed-Din's manuscript have been published in many books and translated into many languages. The manuscript is located at the Bibliotèque Nationale de France, Paris, France. Figure 1 reports a miniature of

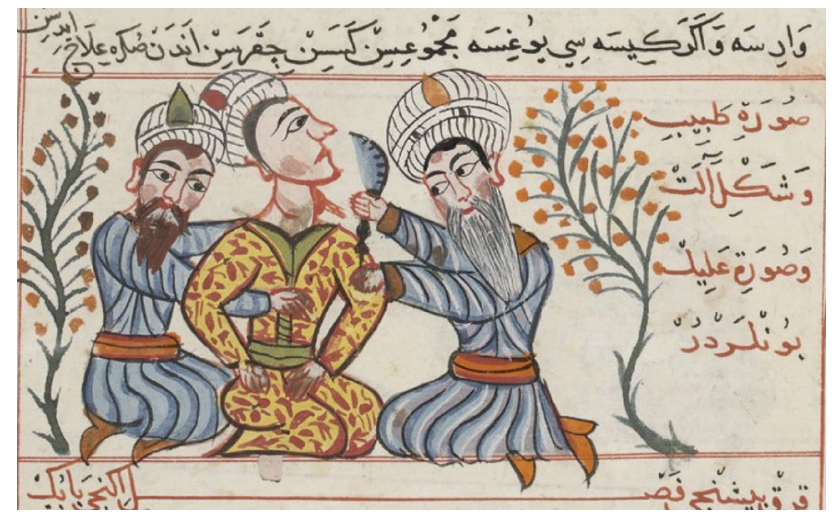

Fig. 1 Miniature author illustrating thyroid surgery (reproduced form Turkish Manuscript of Charaf ed-Din-Ms. Suppl. turc 693, Fol. 85. Source gallica.bnf.fr / Bibliothèque Nationale de France)

E. Martino

enio.martino@gmail.com

1 Department of Endocrinology, University of Pisa, Pisa, Italy

2 Department of Medical Sciences and Public Health, University of Cagliari, Cagliari, Italy the Charaf ed-Din manuscript illustrating surgery for thyroid nodular goitre, according with Abu al-Qasim al-Zahrawi skills, performed using a knife similar to the Turkish sabre. The miniature has been published and discussed by Merke in his book on the history and iconography of the endemic goitre [3].

\section{Compliance with ethical standards}

Conflict of interest The authors declare that there is no conflict of interest.

Ethical approval This article does not contain studies with human participants or animals.

Informed consent For this type of study, no formal consent is required.

\section{References}

1. Théodoridès J, Huard P, Grmek MD (1961) Le premier manuscrit chirurgical turc rédigé par Charaf-ed-Din (1465) et illustré de 140 miniatures. Revue d'histoire des sciences et de leurs applications 14(3-4):363-364

2. Michaleas SN, Tsoucalas G, Androutsos G, Karamanou M (2020) Şerefeddin Sabuncuoğlu: a pioneer surgeon of the Ottoman Era. Erciyes Med J 42(3):350-353

3. Merke F (1984) History and iconography of endemic goitre and cretinism. Hans Huber Publisher, Bern

Publisher's Note Springer Nature remains neutral with regard to jurisdictional claims in published maps and institutional affiliations. 